\title{
Permainan Scrabble untuk Meningkatkan Kemampuan Membaca Awal Siswa Kelas 1 SDN 002 Belakang Padang Kota Batam
}

\author{
Dayarni \\ Sekolah Dasar Negeri 002 Belakang Padang, Batam, Indonesia \\ E-mail: dayarnireva@gmail.com
}

\begin{abstract}
Abstrak
Permasalahan dalam penelitian ini adalalah kemampuan membaca awal siswa kelas 1 Sekolah Dasar Negeri (SDN) 002 di Kecamatan Belakang Padang Kota Batam Provinsi Kepulauan Riau. Penelitian ini bertujuan untuk meningkatkan kemampuan membaca awal siswa kelas 1 dengan menerapkan permainan Scrabble di dalam kelas seta untuk mengetahu faktor yang mempengaruhi peningkatan kemampuan membaca awal siswa kelas 1 menggunakan permainan Scrabble. Jenis penelitian ini adalah Penelitian Tindakan Kelas. Penelitian ini menggunakan pendekatan kualitatif yang didukung pendekatan kuantitatif. Subjek penelitian ini adalah siswa kelas 1 SDN 002 Belakang Padang Kota Batam yang berjumlah 25 orang. Pemilihan subjek penelitian didasarkan pada hasil kemampuan membaca awal siswa yang rendah. Penelitian ini dilakukan pada Bulan Agustus dan September 2019 yang terdiri atas dua siklus. Instrumen penelitian berupa lembar observasi aktivitas siswa, lembar observasi aktivitas guru, dan lembar tes hasil belajar. Data dianalisis dengan statistik deskriptif untuk melihat peningkatan aktivitas dan hasil belajar siswa. Hasil penelitian menunjukkan bahwa pembelajaran dengan menerapkan permainan Scrabble dapat meningkatkan kemampuan membaca awal siswa kelas 1 SDN 002 Belakang Padang Kota Batam. Peningkatan hasil belajar siswa dapat dilihat dari rata- rata hasil belajar siklus 1 adalah 6,4\%, pada siklus 2 naik menjadi $8.8 \%$. Sementara faktor yang mempegaruhi peningkatan hasil belajar membaca siswa adalah strategi permainan Scrabble yang diggunakan guru dan motivasi serta pujian yang diberikan guru kepada siswa. Dari hasil penelitian ini dapat disimpulkan bahwa pembelajaran dengan menerapkan permainan Scrabble dapat meningkatkan kemampuan membaca awal dan hasil belajar siswa pada materi membaca lancar di kelas I SDN 002 Belakang Padang Kota Batam.
\end{abstract}

Kata Kunci: Permainan Scrabble, Kemampuan Membaca, Penelitian Tindakan Kelas

\section{Using Scrabble to Improve Students' Early Reading Ability at Class 1 of SDN 002 Belakang Padang Batam City}

\begin{abstract}
The problem of the research is students' early reading ability at class 1 Sekolah Dasar Negeri (SDN) 002 in Belakang Pandang, Batam city, Kepulauan Riau Province. The purpose of the research is to improve students' early reading ability at class 1 by using Scrabble and to find out factors influencing the students' early reading ability by using Scrabble. The method of the research was Classroom Action Research. The research was qualitative approach that was supported by quantitative approach. The subject of the research was the students at class 1 of SDN 002 Belakang Padang,
\end{abstract}


Batam City that consisted of 25 students. The subject was choosen based on the low early reading ability. The research had done on August to September 2019 that consisted of two cycles. The instruments of the research were teacher and students' observation check list and test. The data was analyzed by using descriptive statistic to find out the improvement of students' activities and students' achievement in reading. The findings of the research showed that Scrabble could improve students' early reading ability at class of SDN 002 Belakang Padang, Batam City. The average score of students' learning achievement in cycle 1 was $6.4 \%$ and in cycle 2 was $8.8 \%$. The factors influencing the improvement of students' early reading ability were teacher strategy, motivation, and teacher's appreciation. In conclusion, Scrabble can improve students' early reading ability and students' learning achievement at class I SDN 002 Belakang Padang, Batam City.

Keywords: Scrabble, Reading Ability, Classroom Action Research

\section{PENDAHULUAN}

Setiap anak berhak mendapatkan pendidikan dan pengajaran dalam pengembangan pribadinya dan tingkat kecerdasan sesuai dengan minat dan bakatnya (Undang-Undang Republik Indonesia No 23 tahun 2002 tentang Perlindungan anak). Sekolah Dasar merupakan salah satu lembaga pendidikan yang formal dengan ratarata anak berusia 7-12 tahun (Peraturan Pemerintah Republik Indonesia No 17 Tahun 2010 tentang Pengelolaan dan Penyelenggaraan Pendidikan). Anak kelas 1 Sekolah Dasar rata-rata berusia 7 tahun. Itu merupakan usia emas (golden ages) (Suyadi, 2014). Mengacu pada pendapat tersebut maka anak Sekolah Dasar

kelas 1 juga berada pada masa golden ages dimana anak mudah dalam menyerap stimulasi, salah satu stimulasi tersebut yaitu berkaitan dengan membaca awal. Membaca awal itu diberikan untuk anak yang berada di kelas rendah atau kelas satu dan kelas dua (Akhidiah, 1992).

Kenyataan yang ada saat ini pelajaran di Sekolah Dasar kelas satu sudah menuntut anak untuk dapat membaca, karena bila belum bisa membaca anak mempunyai kendala dalam mengikuti pelajaran. Membaca merupakan salah satu fungsi yang paling penting dalam hidup dan dapat dikatakan bahwa semua proses belajar didasarkan pada kemampuan membaca (Yulia, 2004). Pembelajaran membaca di Sekolah Dasar dirancang sedemikian rupa sehingga anak tidak merasa terbebani, dan bosan maka suasana belajar dapat dibuat dengan menyenangkan. Kemampuan membaca awal anak sangat penting diberikan di kelas rendah, hal tersebut bertujuan supaya anak memiliki kemampuan melafalkan tulisan dan sebagai dasar untuk dapat membaca lanjut (Akhidiah, 1992). Kepala SDN 002 Belakang Padang Kota Batam menyatakan bahwa kemampuan membaca awal juga penting dimiliki anak sebelum memasuki Sekolah Dasar, diharapkan ketika memasuki Sekolah Dasar anak tidak kaget dengan pelajaran Sekolah Dasar yang banyak tulisannya dan paling tidak anak sudah mempunyai bekal untuk menghadapi pelajaran di Sekolah Dasar. Membaca permulaan (membaca awal) lebih menekankan pada pengenalan dan pengucapan lambang-lambang bunyi yang berupa huruf, kata dan kalimat dalam bentuk 
sederhana (Zubaidah, 2013). Mengacu pendapat tersebut pengucapan lambanglambang bunyi dapat menghasilkan suatu makna.

Tahap perkembangan kemampuan membaca anak ada empat (Susanto, 2011) yaitu: a) Tahap timbulnya kesadaran terhadap tulisan, b) Tahap membaca gambar, c) Tahap mengenal bacaan dan d) Tahap membaca lancar. Berikut ini penjabaran dari keempat tahap tersebut:

a) Tahap timbulnya kesadaran terhadap tulisan, anak belajar menggunakan buku dan menyadari bahwa buku itu penting. Anak senang membawa buku kesukaannya dan membolak-baliknya. Dalam hal ini, jika anak menyukai buku tersebut maka anak akan semangat dan senang dalam membaca. Dari buku ini, anak akan mengenal bentuk huruf satu per satu.

b) Tahap membaca gambar, anak usia Taman Kanak-Kanak memandang diri sebagai pembaca dan mulai melibatkan diri dalam kegiatan membaca, ia pura-pura membaca buku meskipun kadang bukunya terbalik, memberi makna gambar, menggunakan bahasa buku walaupun tidak cocok dengan tulisannya.

c) Tahap mengenal bacaan, anak pada tahap ini dapat menggunakan tiga sistem bahasa, seperti fonem (bunyi huruf), semantik (arti kata), sintaksis (aturan kata atau kalimat) secara sama-sama. Anak yang sudah tertarik pada bahan bacaan mulai mengingat kembali cetakan hurufnya dan konteksnya. Anak mulai mengenal tanda-tanda yang ada pada benda-benda di lingkungannya berdasarkan pengalaman yang diperolehnya.

d) Tahap membaca lancar, berarti anak dapat mengenal berbagai huruf hingga anak dapat mengeja per suku kata menjadi kalimat. Dalam tahap ini berarti anak sudah dapat membaca lancar berbagai jenis buku.

Berdasarkan pendapat ahli di atas dapat disimpulkan bahwa tahap membaca awal yaitu tahap membaca gambar dan tahap pengenalan bacaan. Tahap tersebut diantaranya ditandai dengan anak dapat mengenali cetakan seperti mengenali simbol-simbol huruf, kata maupun gambar yang ada di lingkungan, mulai mengeja dan membaca kata yang ada gambarnya, mengetahui hubungan antara bunyi dan bentuk huruf, mengenal tanda-tanda yang ada pada benda-benda di lingkungannya

Kemampuan untuk meningkatkan daya ingat anak perlu diasah, sehingga otak dapat mempengaruhi hasil akhir yang dicapai. Mengasah kemampuan otak adalah cara untuk meningkatkan kualitas kecerdasan dan pikiran dari seseorang. Biasanya anak-anak yang sedang tumbuh berkembang butuh sekali untuk mengasah kemampuan otaknya sebab anak-anak yang sedang tumbuh berkembang mudah sekali untuk diasah kemampuan otaknya maka dari itu anak-anak yang sedang tumbuh berkembang itu hendaknya disuguhi dengan media-media pembelajaran untuk membantu anak meningkatkan kemampuan membaca awal. Salah satunya untuk mengasah kemapuan otak adalah melalui penggunaan media permainan Scrabble. Scrabble merupakan sebuah media yang berbentuk permainan dengan fungsi mengasah otak atau menstimulasi perkembangan otak. Scrabble ini juga merupakan permainan berbentuk papan dan cara bermainnya dengan menyusun 
kata yang memiliki makna. Dengan permainan yang mengasah otak ini maka secara tidak sengaja anak akan meningkatkan penguasaan kosakata dan membaca yang kemudian dapat digunakan dalam merangkai kalimat (subjek-objek-prediket). Scrabble adalah permainan yang dapat dimainkan oleh dua, tiga atau empat orang peserta dalam waktu tertentu. Permainan ini merupakan permainan menyusun kata di atas papan berkotak-kotak sejumlah 15 kolom dan 15 baris dengan menggunakan kepingan huruf sejumlah 100 tiles. Pemain menggunakan kepingan huruf untuk membentuk kata, baik secara mendatar maupun menurun, layaknya bermain teka-teki silang (Pratt, 2009).

Berdasarkan observasi yang dilakukan pada bulan Juli 2019, kemampuan membaca awal di Kelas 1 SDN 002 Belakang Padang Kota Batam masih perlu ditingkatkan karena anak masih ada yang belum dapat mengenali huruf maupun melafalkan huruf. Sebagian hal ini dikarenakan media pembelajaran yang digunakan guru kurang menarik dalam proses pembelajaran terutama untuk membaca awal pada anak. Media yang digunakan dalam kegiatan anak seperti lembar kerja, flash card sederhana, dan berbagai macam gambar sesuai tema kemudian ditempel dikarton. Kegiatan kerja anak dalam proses pembelajaran seperti meniru garis jadi huruf, menebalkan huruf menjadi kata, menyebutkan kembali sesuai gambar, menyesuaikan dan menyebutkan huruf awal sesuai gambar (flash card). Kegiatan ini juga sering dilakukan setiap hari dalam kegiatan anak, sehingga anak juga merasa bosan atau jenuh dalam mengerjakan hal tersebut. Selain itu, anak-anak juga masih ada yang kurang dapat membedakan dan mengenali huruf, karena dalam setiap proses pembelajaran guru mengenalkan huruf melalui menulis (menarik garis), menebalkan huruf, dan kartu bergambar disertai kata. Proses kerja anak dalam kartu bergambar disertai kata, anak hanya mengenal huruf awal dan mencocokkan huruf dengan kata yang sudah tertera digambar saja, namun sebagian anak hanya bisa mencocokkan huruf awal dan tidak dapat mengenal serta menyebutkan huruf awal tersebut. Pengetahuan tentang huruf-huruf penting untuk anak karena berhubungan dengan kemampuan membaca awal anak, sehingga untuk memasuki jenjang pendidikan selanjutnya tidak mengalami kendala dalam mengikuti pelajaran.

\section{METODE}

Metode penelitian yang digunakan dalam penelitian ini adalah metode Penelitian Tindakan Kelas (PTK). Hopkins (2014) mendefinisikan bahwa penelitian tindakan adalah tentang studi sistematis upaya untuk meningkatkan praktik pendidikan oleh kelompok peserta melalui tindakan praktis mereka sendiri dan melalui refleksi mereka sendiri atas efek dari tindakan itu. Subjek dalam penelitian ini adalah siswa kelas 1 SDN 002 Belakang Padang Kota Batam yang terdiri dari 25 orang. Penelitian ini dilaksanakan mulai dari Bulan Agustus sampai dengan Bulan September 2019.

Penelitian Tindakan Kelas ini merupakan penelitian dengan proses siklus. Setiap siklus terdiri dari beberapa langkah. Model yang dideskripsikan oleh Mertler (2012: 38) ini dikenal sebagai action research spiral yang terdiri dari empat langkah. Prosedur penelitian ini meliputi merencanakan (planing), tindakan (acting), mengamati (observation), refleksi (reflection) (Kemmis dan Mc Taggart, 2000). Modelnya dapat dilihat pada gambar di bawah ini: 


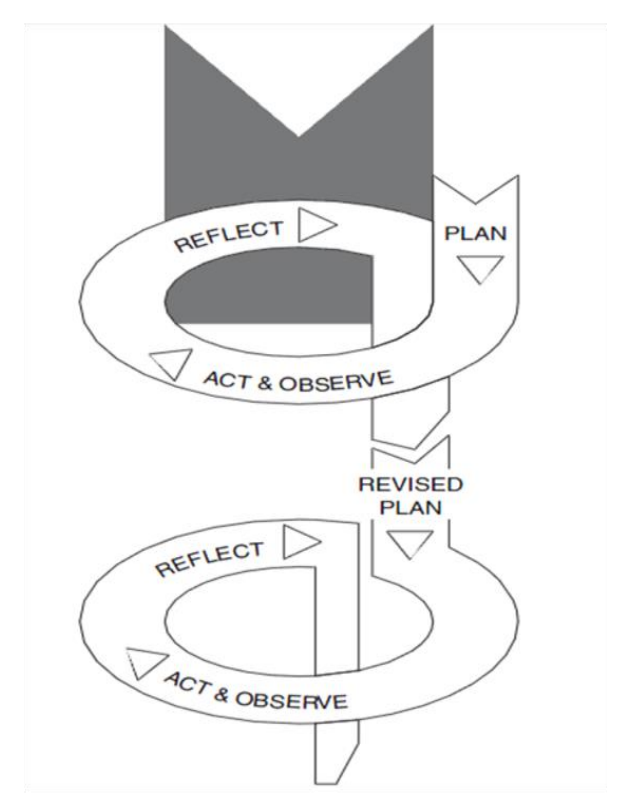

Figure 1. Prosedur Penelitian

\section{a. Plan}

Pada langkah ini, peneliti merencanakan beberapa kegiatan untuk diterapkan di kelas. Kegiatan akan dijelaskan dalam rencana pelajaran.

b. Action

Pada langkah ini, peneliti mengimplementasikan kegiatan yang telah dirancang. Ini akan dibagi menjadi tiga langkah seperti: aktivitas awal, aktivitas sementara, dan aktivitas akhir. Dalam kegiatan pra peneliti memulai kelas dengan sapaan, memeriksa daftar hadir siswa dan memberikan motivasi kepada siswa sebelum memulai pelajaran. Aktivitas sementara kegiatannya yaitu peneliti menjelaskan materi membahas dan memperkenalkan permainan Scrabble kepada siswa.

c. Observation

Pada langkah ini, peneliti mengamati dan mencatat semua kegiatan ketika peneliti melakukan proses belajar mengajar di kelas dengan menggunakan permainan Scrabble. Peneliti mencatat semua kegiatan terjadi dalam daftar observasi dan catatan lapangan. d. Reflection

Dalam langkah ini, peneliti menganalisis dan umpan balik hasil tindakan dan menafsirkan data yang diperoleh untuk membuat keputusan untuk direvisi dalam siklus berikutnya.

Dalam mengumpulkan data peneliti menggunakan beberapa instrumen yaitu Observasi checklist dan dokumen.

\section{HASIL DAN PEMBAHASAN}

Perlakuan dilakukan berdasarkan jadwal yang ditetapkan oleh peneliti. Pengambilan data dilakukan pada anak di kelas 1 Sekolah Dasar. Permainan Scrabble ini baru pertama kali diterapkan di Kelas 1 SDN 002 Belakang Padang Kota Batam. Permainan ini awalnya sangat sulit dicerna atau dilakukan anak dalam proses pembelajaran berlangsung, sehingga harus adanya pengulangan setiap harinya.

Dalam kegiatan inti diarea bahasa yang pertama peneliti memperkenalkan permainan Scrabble kepada anak. Setelah peneliti memperkenalkan permainan tersebut, anak dapat memperaktekkan langsung permainan tersebut.

Permainan ini umumnya dilakukan 2-4 orang, namun untuk ditingkat Sekolah Dasar khususnya di kelas 1 Sekolah Dasar permainan ini dilakukan hanya 1 orang anak saja guna untuk dapat membantu anak dalam membaca awal sehingga peneliti juga tidak kewalahan dalam proses permainan berlangsung. Permainan ini harus digunakan dengan berbagai kosa kata yang berada dekat dengan lingkungannya, dengan demikian anak akan dapat berpikir cepat dan dapat memahami setiap huruf yang ada didalam kosakata tersebut. Artinya anak 
dapat menambahkan huruf yang hilang dari kosa kata yang ingin diisi anak.

a. Plan

Aktivitas yang pertama peneliti lakukan yaitu perencanaan bagaimana aktivitas di kelas, perencanaan ini adalah titik kunci yang dibutuhkan dalam kegiatan implementasi permainan Scrabble di dalam kelas.

\section{b. Action}

Pada pertemuan pertama peneliti menjelaskan tentang permainan Scrabble kepada siswa, setelah itu peneliti menunjukkan dan mengajarkan siswa bagaimana cara permainan Scrabble tersebut di dalam kelas. Pertemuan kedua, ketiga, dan keempat setiap kegiatan implementasi dilakukan dengan rencana pembelajaran dan langkah-langkah pembelajaran dalam rencana pembelajaran dengan penerapan permaninan Scrabble untuk meningkatkan kemampuan membaca awal siswa kelas I SDN 002 Belakang Padang Kota Batam, kegiatan atau aktivitas dibagi menjadi tiga fase yaitu aktivitas awal, aktivitas sementara, dan aktivitas akhir.

Berdasarkan data hasil pos test dan ulangan harian daya serap siswa selama pembelajaran menggunakan permainan Scrabble siklus I dapat dilihat pada tebel di bawah ini.

Tabel 1. Daya Serap Siswa Siklus 1

\begin{tabular}{|c|c|c|c|}
\hline \multirow[t]{3}{*}{ Interval } & \multicolumn{3}{|c|}{ Daya Serap } \\
\hline & Pos & Pos Test & UH I N \\
\hline & Test 1 & 2 & $(\%)$ \\
\hline $85-100$ & - & - & _ \\
\hline $71-84$ & $4(16)$ & $6(24)$ & $8(32)$ \\
\hline $65-70$ & $12(48)$ & $5(2)$ & $5(2)$ \\
\hline$<65$ & $9(36)$ & $14(56)$ & $12(48)$ \\
\hline & $25(100)$ & $25(100)$ & $25(100)$ \\
\hline & 6.7 & 6.4 & 6.4 \\
\hline & Cukup & Kurang & Kurang \\
\hline
\end{tabular}

test 1,2 , dan ulangan harian mengalami peningkatan walaupun dari rata-rata sebenarnya turun. Pada setiap pos tes dan ulangan harian di siklus I ini, tidak satu orang siswa yang masuk kategori baik sekali. Pada pertemuan satu, siswa yang mendapat kategori baik cuma 4 orang $(16 \%)$, pertemuan kedua meningkat menjadi 6 orang (24\%), di ulangan harian menjadi 8 orang (32\%). Kategori cukup malah mengalami penurunan dari 12 orang (48\%) pada pos test 1 , menurun menjadi 5 orang (2\%) pada pos test 2 dan ulangan harian.

Siswa yang masuk kategori kurang juga meningkat, yakni 9 orang (36\%) pada pos tes 1,14 orang $(56 \%)$ pos test 2, dan 12 orang (48\%) di ulangan harian. Pada pos test 1 , ratarata siswa termasuk kategori cukup, pos test 2 dan ulangan harian menurun menjadi kategori kurang.

Data ulangan harian siklus I sudah mengalami peningkatan, jika dibandingkan dengan nilai rata-rata ulangan harian siswa sebelum menggunakan permainan Scrabble yakni 6,1 masih di bawah KKM dengan kategori kurang. Setelah pembelajaran menggunakan permainan Scrabble, nilai rata-rata ulangan harian siswa sudah meningkat, yakni 6,4 dengan kategori cukup walaupun masih belum mencapai KKM.

Pada siklus satu ini masih banyak nilai siswa yang di bawah KKM, yakni pos tes pertama 21 orang yang mendapat kategori cukup, pos tes kedua 19 orang yang mendapat kategori kurang, dan pada ulangan harian 17 orang yang juga mendapat kategori kurang.

Ketuntasan belajar siswa dengan menggunakan permainan Scrabble pada siklus 1 diakhiri dengan melaksanakan tes hasil belajar dengan jumlah soal sebanyak 20 butir berbentuk objektif dan diikuti oleh 25 
orang siswa. Data ini digunakan untuk mengetahui tingkat penguasaan siswa terhadap materi yang dipelajari pada siklus I. Berdasarkan hasil ulangan harian dapat dilihat ketuntasan belajar siswa pada siklus 1 pada tabel berikut ini:

Tabel 2. Persentase Ketuntasan Siklus I

\begin{tabular}{cccc}
\hline No & frekuensi & Persentase $(\%)$ & Klasifikasi \\
\hline 1 & 8 & 32 & Tuntas \\
2 & 17 & 68 & Tidak \\
\hline
\end{tabular}

Tabel 2 di atas menjelaskan bahwa dari 25 orang siswa, 8 orang (32\%) sudah memperoleh nilai di atas KKM, yakni 75 sedangkan 17 orang (68\%) memperoleh nilai di bawah KKM. Hal ini menandakan bahwa pembelajaran belum berhasil maksimal.

Sedangkan hasil belajar siswa menggunakan pernainan Scrabble pada siklus 2 dapat ketahui bahwa berdasarkan data hasil pos test dan ulangan harian daya serap siswa selama pembelajaran menggunakan permainan Scrabble pada siklus2 dapat dilihat pada table di bawah ini.

Tabel 3. Daya Serap Siswa Siklus 2

\begin{tabular}{|c|c|c|c|}
\hline \multirow[t]{3}{*}{ Interval } & \multicolumn{3}{|c|}{ Daya Serap } \\
\hline & Post Test & Post & UH I N (\%) \\
\hline & 1 & Test 2 & \\
\hline $85-$ & $7(28)$ & $18(72)$ & $20(80)$ \\
\hline $71-84$ & $16(64)$ & $8(32)$ & $5(20)$ \\
\hline $65-70$ & $2(8)$ & - & - \\
\hline$<65$ & - & - & - \\
\hline & $25(100)$ & $25(100)$ & $25(100)$ \\
\hline & 7,8 & 8,6 & 8,8 \\
\hline & Baik & Baik & Baik Sekali \\
\hline
\end{tabular}

Tabel 3 di atas menjelaskan bahwa daya serap siswa siklus 2 pada pos test 1, 2, dan ulangan harian mengalami peningkatan. Pada pertemuan pertama (pos tes 1) terdapat
7 orang (28\%) masuk kategori baik sekali, 16 orang (64\%) kategori baik, 2 orang (8\%) kategori cukup, dan tidak ada siswa yang masuk kategori kurang. Rata-rata nilai siswa pada pertemuan pertama ini masuk kategori baik. Pada pertemuan dua (pos test 2) terdapat 18 orang (72\%) siswa yang masuk kategori baik sekali, 8 orang (32\%) kategori baik, dan tidak seorang siswapun yang masuk kategori cukup atau kurang. Nilai rata-rata siswa pada pertemuan dua masuk kategori baik sekali. Pada ulangan harian di siklus 2 ini, 20 orang $(80 \%)$ masuk kategori baik sekali, dan sisanya 5 orang $(20 \%)$ masuk kategori baik. Nilai rata-rata siswapun pada ulangan harian ini masuk kategori baik sekali.

Data di atas menunjukkan bahwa daya serap siswa mengalami peningkatan. Hal ini dapat dilihat pada hasil ulangan harian siswa siklus 1, yakni 6,4 dengan kategori cukup, naik menjadi 8,8 pada siklus 2 dengan kategori baik sekali.

Pembelajaran membaca awal menggunakan permainan Scrabble pada siklus 2 diakhiri dengan melaksanakan tes hasil belajar, jumlah butir soal sebanyak 20 butir berbentuk objektif yang diikuti oleh 25 orang siswa. Data ini digunakan untuk mengetahui tingkat penguasaan siswa terhadap materi yang dipelajari pada siklus 2. Berdasarkan hasil ulangan harian dan analisa data secara ringkas dapat dilihat pada tabel berikut ini:

Tabel 4. Persentase Ketuntasan Siklus 2

\begin{tabular}{ccc}
\hline No & Frekuensi & Persentase $(\%)$ \\
\hline 1 & 25 & 100 \\
2 & - & - \\
\hline
\end{tabular}

Tabel 4 sebelumnya menjelaskan bahwa dari 25 orang siswa, semuanya memperoleh nilai di atas KKM, yakni 
25 orang $(100 \%)$. Hal ini menandakan bahwa pembelajaran membaca pemahaman berhasil.

\section{c. Observation}

Pengamatan dilakukan pada pertemuan kedua dan ketiga, diamati dan dinilai pada pertemuan keempat. Untuk memperoleh data hasil penelitian ini, peneliti menggunakan teknik pengumpulan data dengan observasi pada sampel subjek. Skor tertinggi adalah 4 dan skor terendah adalah 1 . Untuk memberikan nilai pada rerata dari jumlah skor indikator untuk masing-masing anak dan nilai secara keseluruhan anak setiap indikator.

\section{d. Reflection}

Pembelajaran

membaca menggunakan permainan Scrabble ini dapat meningkatkan aktivitas maupun hasil belajar. Siswa terlihat aktif selama proses pembelajaran membaca menggunakan permainan Scrabble. Hal ini disebabkan karena siswa termemotivasi dengan permainan Scrabble ini. Pembelajaran pada siklus ini mengalami peningkatan bukan hanya dari segi aktivitas siswa, aktivitas guru juga mengalami peningkatan. Guru Lebih aktif memantau kegiatan siswa. Dalam hal presentasi kelas, guru menjelaskan kembali tentang materi pelajaran, namun lebih ditekankan kepada hal-hal yang kurang dipahami siswa. Reward yang diberikan guru sebagai motivasi berhasil meningkatkan aktivitas siswa dalam belajar. Data untuk hasil belajar menunjukkan, ada 4 orang siswa yang memperoleh nilai 100 pada ulangan harian dan tidak ada nilai di bawah 80 apalagi nilai di bawah KKM, yaitu 75 . Data menunjukkan semua siswa masuk kategori tuntas dalam ulangan harian II. Ada 3 orang siswa yang nilainya naik sekitar $40 \%$ dan 2 orang nilainya naik $50 \%$. Dari hasil analisa data pada siklus II ini dapat disimpulkan bahwa aktivitas dan hasil belajar Bahasa Indonesia pada materi membaca lancar selama pembelajaran menggunakan permainan Scrabble mengalami peningkatan. Hasil refleksi di atas telah menjelaskan bahwa aktivitas dan hasil belajar siswa telah mencapai hasil yang optimal. Peneliti bersama kolaborator mengambil kesimpulan bahwa penelitian tidak perlu dilanjutkan pada siklus berikutnya.

Berdasarkan data hasil pos test dan ulangan harian daya serap siswa selama penerapan pembelajaran membaca menggunakan permainan Scrabble pada siklus I dan siklus 2 dapat dilihat pada tabel berikut ini:

Tabel 5. Daya Serap Siswa Siklus 1 dan 2

\begin{tabular}{cccc}
\hline Siklus & $\begin{array}{c}\text { DS } \\
(\%)\end{array}$ & Kategori & Peningkatan \\
\hline 1 & 6.4 & Kurang & $2.4 \%$ \\
2 & 8.8 & Baik & \\
& \multicolumn{3}{c}{ Sekali } \\
\hline
\end{tabular}

Dari tabel 5 di atas menjelaskan bahwa terjadi peningkatan daya serap siswa. Rata-rata daya serap siklus I adalah 6,4\%, sedangkan rata-rata daya serap siswa siklus II $8.8 \%$. Persentase daya serap siswa meningkat sebesar $2,4 \%$.

Ketuntasan belajar siswa selama pembelajaran menggunakan permainan Scrabble pada siklus I dan II dapat dilihat dari tes hasil belajar. Tes hasil belajar dilaksanakan dengan memberikan 20 butir soal berbentuk objektif. Analisa data secara ringkas dapat dilihat pada tabel 6 berikut ini:

Tabel 6. Ketuntasan Siswa Siklus 1 dan 2

\begin{tabular}{llll}
\hline Kriteria & Siklus 1 & Siklus 2 & Keterangan
\end{tabular}




\begin{tabular}{cccc}
\hline Tuntas & $8(32)$ & $25(100)$ & Naik 68\% \\
Tidak & $17(68)$ & - & Berkurang \\
Tuntas & & & $17 \%$ \\
\hline
\end{tabular}

Berdasarkan Tabel 6 di atas, dapat dilihat bahwa ketuntasan siswa siklus 1 adalah 8 orang (32\%). Pada siklus 2meningkat menjadi 25 orang $(100 \%)$. Siswa yang tidak tuntas pada siklus 1 , yakni 17 orang (68\%) sedangkan di siklus 2 tidak seorangpun siswa yang belum tuntas.

\section{Pembahasan}

Peneliti menerapkan permainan di Kelas 1 SDN 002 Belakang Padang Kota Batam berupa permainan Scrabble. Pemilihan Scrabble dalam hal ini berlandaskan pada manfaat permainan itu sendiri yakni permainan dapat dipakai untuk berbagai tujuan pendidikan dengan mengubah sedikit alat ataupun persoalannya, misal mempraktikkan keterampilan membaca (Sadiman, 2011). Permainan ini umumnya dilakukan 2-4 orang. Anakanak juga masih ada yang belum tahu dalam membedakan huruf yang hampir sama bentuknya dan anak juga sulit dalam membaca awal yang melebihi dari dua suku kata. Kata yang sulit untuk dibaca oleh anak sebagian besar berupa kata yang mengandung lebih dari dua suku kata seperti, kata stro-beri, ram-bu-tan, du-ri-an, dan sebagainya. Kemudian huruf yang sangat jarang dijumpai dalam setiap kata seperti huruf $\mathrm{f}$, huruf $\mathrm{q}$, huruf $\mathrm{v}$, huruf $w$, huruf $x$, dan huruf $z$, sehingga beberapa anak tidak dapat melafalkan huruf tersebut. Selain itu, ubin huruf Scrabble terkadang disusun oleh subjek dengan cara terbalik. Misalnya yang seharusnya huruf "q" disusun sebagai huruf "b", huruf " $d$ " disusun sebagai huruf "p" atau sebaliknya dan huruf "n" disusun sebagai huruf "u" atau sebaliknya. Namun, karena adanya pengulangan treatment setiap pertemuannya anak-anak mengalami perubahan yang baik. Anak yang belum dapat mengenal huruf, mulai dapat mengenal huruf. Anak yang mulai dapat mengenal huruf menjadi dapat mengenal huruf. Permainan ini dikatakan selesai bermain jika anak sudah dapat mengenal huruf, melafalkan huruf, membentuk kata dan mengeja kata atau kalimat sederhana dengan benar.

Permainan Scrabble terhadap kemampuan membaca awal saat pos tes, anak-anak semakin paham dan hanya ada beberapa anak yang belum terlalu paham dalam permainan ini. Namun untuk setiap indikator yang digunakan peneliti dalam lembar observasi tercapai sesuai dengan yang diinginkan.

Ada peningkatan kemampuan membaca awal anak antara sebelum dan sesudah menerapkan permainan Scrabble. Dalam hal ini, setelah diberinya perlakuan (action) terdapat perubahan yang besar dibandingkan sebelum perlakuan (action). Dengan demikian permainan Scrabble berpengaruh terhadap kemampuan membaca awal anak di Kelas 1 SDN 002 Belakang Padang Kota Batam. Hal ini sesuai dengan teori yang dikemukan oleh Rahim (2008) mengemukakan bahwa membaca adalah suatu proses yang melibatkan banyak hal, tidak hanya melafalkan tulisan tetapi juga melibatkan aktivitas visual, berpikir, psiko linguistik dan metakognitif. Membaca sebagai proses visual yakni proses menerjemahkan simbol ke dalam suatu bunyi. Membaca sebagai proses berpikir yaitu membaca yang mencakup pengenalan kata, pemahaman literal, interpretasi, membaca kritis dan membaca kreatif. Membaca sebagai proses linguistik, dengan skemata pembaca membantunya untuk membangun makna, sedangkan untuk proses metakognif, melibatkan perencanaan, pembetulan strategi dan 
pengevaluasian. Teori yang kedua yaitu oleh Jamaris (2006) kemampuan membaca dan menulis dapat dilihat dari kemampuan anak dalam melakukan koordinasi gerakan visual, kemampuan anak dalam melakukan diskriminasi secara visual, kemampuan kosakata, kemampuan diskriminasi auditoria dapat membedakan suara yang didengar.

Daya serap siswa selama pembelajaran menggunakan permainan Scrabble pada siklus I dan II mengalami peningkatan. Rata-rata daya serap siswa pada siklus I adalah 6,4 \%. Pada siklus II rataratanya meningkat menjadi $8,8 \%$. Peningkatan daya serap ini erat kaitannya dengan penggunaan permainan Scrabble didalam pembelajaran membaca. Permainan Scrabble ini dapat memotivasi siswa untuk menjadi lebih aktif dikelas.

Saat proses pembelajaran berlangsung, guru selalu memantau, memberi bimbingan dan memotivasi siswa serta diakhir pembelajaran memberikan penghargaan kepada siswa yang terbaik melakukan aktivitas. Bimbingan dan penghargaan yang diberikan guru dapat meningkatkan hasil belajar. Hasil penelitian ini sesuai dengan pendapat Sardiman (2011: 94), mengatakan bahwa apabila ada siswa yang sukses, yang berhasil menyelesaikan tugas dengan baik, perlu diberikan pujian. Dengan pujian yang tepat akan memupuk suasana yang menyenangkan dan mempertinggi gairah belajar serta sekaligus akan membangkitkan harga diri.

Ketuntasan belajar pada siklus 1, terdapat 8 orang siswa yang sudah tuntas. Ketuntasan itu meningkat menjadi 25 orang pada siklus 2 . Peningkatan ketuntasan belajar siswa erat kaitannya dengan strategi yang digunakan guru yaitu permainan Scrabble untuk meningkatkan kemampuan membaca awal siswa kelas 1 SDN 002 Belakang Padang Kota Batam.

\section{KESIMPULAN}

Permainan Scrabble baru pertama kali diterapkan di Kelas 1 SDN 002 Belakang Padang Kota Batam. Permainan ini awalnya sangat sulit dicerna atau dilakukan anak dalam proses pembelajaran berlangsung, sehingga harus adanya pengulangan setiap harinya. Permainan ini dilaksanakan untuk meningkatkan kemampuan membaca awal siswa dengan baik. Permainan ini dikatakan selesai bermain jika anak sudah dapat mengenal huruf, melafalkan huruf, membentuk kata dan mengeja kata atau kalimat sederhana dengan benar. Permainan Scrabble dapat meningkatkan kemampuan membaca siswa di Kelas 1 SDN 002 Belakang Padang Kota Batam. Berdasarkan hasil penelitian dapat disimpulkan bahwa permainan Scrabble dapat meningkatkan hasil belajar siswa pada materi membaca. Hal ini dapat dilihat dari perbandingan hasil belajar siswa antara siklus 1, yakni $6,4 \%$ dengan kategori cukup dan siklus 2, yakni 8,8\% dengan kategori sangat baik. Ada dua faktor yang mempengaruhi peningkatan kemampuan membaca awal siswa kelas 1 SDN 002 Belakang Padang Kota Batam yaitu strategi permainan Scrabble yang digunakan guru dan motivasi serta pujian yang diberikan guru kepada siswa sehingga siswa lebih aktif dalam belajar membaca.

\section{DAFTAR PUSTAKA}

Abas. S. 2006. Pembelajaran Bahasa Indonesia yang Efektif di Sekolah Dasar. Jakarta: Depdiknas. 
Abdurrahman, M. 2003. Pendidikan Bagi Anak Kesulitan Belajar. Jakarta: Rineka Cipta.

Akhidiah, S. 1992. Bahasa Indonesia 1. Jakarta: Depdikbud.

Aminah. 2011. Peningkatan Keterampilan Membaca Lancar melalui Permainan Scrabble pada Siswa Kelas I Sekolah Dasar. Sarjana pendidikan Jurusan Pendidikan Sekolah Dasar Fakultas Ilmu Pendidikan Universitas Negeri Semarang.

Arifin, Z. 2011. Penelitian Pendidikan. Bandung : Remaja Rosdakarya.

Arikunto, S. 2006. Prosedur penelitian Suatu pendekatan Praktik. Jakarta: PT Rineka Cipta. . 2010. Prosedur Peneltian. Jakarta : Rineka Cipta.

Azwar, S. 2003. Metode Penelitian. Yogyakarta: Pusataka Pelajar.

Dhieni, N. 2008. Metode Pengembangan Bahasa. Jakarta: Universitas Terbuka.

Hainstock, E.G. 2002. Montessori untuk Anak Prasekolah. Jakarta: Pustaka Delaprasta.

Hartati, S. 2005. Perkembangan Belajar Pada Anak Usia Dini. Jakarta: Depdiknas.

Hinebaugh, J.P. 2009. A Board Game Education. United States America: Rowman \& Littlefield Education.

Pratt, A. L. Scrabble: Encyclopedia of Play in Today's Society. 2009.
SAGE Publications. 10 Okt. 2011.

Rahim, F. 2008. Pengajaran Membaca Di Sekolah Dasar. Jakarta: Bumi Aksara.

Sadiman, A.S. 2011. Media Pendidikan, Pengertian, Pengembangan, dan Pemanfaatannya. Jakarta: PT. Raja Grafindo Persada.

Santrock, J. W. 2002. Life - Span Development Jilid I (Alih Bahasa: Juda Damanik dan Achmad Chusairi). Jakarta: Erlangga.

Sardiman. 2011. Interaksi dan Motivasi Belajar Mengajar. Jakarta: Raja Grafindo Persada.

Sugiyono. 2007 Metode Penelitian Kuantitatif, Kualitatif dan $R$ \& $D$. Bandung: Alfabeta.

Susanto, A. 2011. Perkembangan Anak Usia Dini. Jakarta: Kencana Prenada Media Group. .2009. Metode Penelitian Pendidikan, Bandung: Alfabeta. .2010. Metode Penelitian Pendidikan, Bandung: Alfabeta.

Sundayana, R. 2014. Statistika Penelitian Pendidikan. Bandung: Alfabeta.

Undang-undang Nomor 20 Tahun 2003 tentang Sistem Pendidikan Nasional.

Undang-Undang Republik Indonesia No 23 tahun 2002 tentang Perlindugan anak. 
Usman, H. 1993. Metodologi Penelitian Sosial. Jakarta: PT. Bumi Aksara.

Yulia, A. 2004. Cara Menumbuhkan Minat Baca Anak. Jakarta: PT Elex Media Komputindo.

Yusuf, M. 2005. Pendidikan bagi Anak dengan Problema Belajar. Jakarta: Depdiknas.
Zubaidah, E. 2013. Draf Penulisan Buku Kesulitan Membaca Permulaan pada Anak Diagnosa dan Cara Mengatasinya. Yogyakarta: Universitas Negeri Yogyakarta 